\title{
SUSTAINABILITY AND SOCIO-ENVIRO-TECHNICAL SYSTEMS: MODELING TOTAL COST OF OWNERSHIP IN CAPITAL FACILITIES
}

\author{
Annie R. Pearce \\ Virginia Tech \\ Department of Building Construction \\ Blacksburg, VA 24061, USA
}

\author{
Kristen L. Sanford Bernhardt \\ Lafayette College \\ Dept. of Civil \& Environmental Engineering \\ Easton, PA 18042, USA
}

\author{
Michael J. Garvin \\ Virginia Tech \\ Myers-Lawson School of Construction \\ Blacksburg, VA 24061, USA
}

\begin{abstract}
Investment in sustainability strategies and technologies holds promise for significant cost savings over the operational phase of a facility's life cycle, while more effectively meeting stakeholder needs. However, accurately estimating the first costs of a green project during the early concept development stages is challenging, and effective ways to comprehensively predict potential lifecycle cost impacts of sustainability strategies do not exist. This paper describes a agent-based model (ABM) of the Total Cost of Ownership of green facilities applicable at the earliest stages of concept development. An ABM approach captures the social, environmental, and engineering systems that characterize a facility's life cycle cost. It permits evaluating the impact of the institutional and industry environment on facility life cycle performance, and also captures the cost impacts of tightly coupled facility systems that characterize green design.
\end{abstract}

\section{INTRODUCTION: SUSTAINABILITY AND BUILT ENVIRONMENT SYSTEMS}

As impacts of humans on the environment at both local and global scales become increasingly apparent, sustainability and sustainable development have emerged as goals for human activity toward which all actions should aspire (e.g., MDG 2000; WCED 1987). Sustainability implies the ability of a system to maintain itself or be maintained over time without threatening the stability of other systems upon which it depends. However, human-designed systems often exhibit complexity and emergent behaviors that make their sustainability difficult to evaluate. The built environment - constructed facilities and infrastructure is one example of this kind of complex system. This paper presents a new approach to operationalizing sustainability for the capital facilities that make up the built environment and describes efforts underway to implement that approach using Agent-Based Modeling (ABM).

\subsection{Built Environment Sustainability}

The built environment is an essential component of human activities and a subject of increasing interest for sustainability research and practice. One reason for this is the increasingly undeniable effects of the 


\section{Pearce, Sanford-Bernhardt, and Garvin}

built environment on natural systems. Major environmental impacts exacerbated by construction activities include climate change; ozone depletion; soil erosion; desertification; acidification; loss of biodiversity; land, water, and air pollution; depletion of fisheries; and consumption of resources such as fossil fuels, minerals, and gravel (Hill and Bowen 1997; Kibert 2008; Roodman and Lenssen 1995; Shah 2006). Built facilities also have a considerable impact on the humans who occupy and use them for various purposes. Indoor air quality, lighting, acoustics, and thermal comfort are strongly related to occupant health, comfort, and productivity (Kats 2003). While evaluating the exact financial impact of healthier, more comfortable facilities is difficult, potential U.S. annual savings or productivity gain from improvements in indoor environments are in the range of $\$ 43$ billion to $\$ 236$ billion annually (Fisk 2000; Fisk and Rosenfeld 1997; Kats 2003). Opportunities abound to improve environmental quality and building performance while creating better human habitats. Sustainable construction - construction that meets the needs of stakeholders while not compromising the ability of non-stakeholders or future humans to meet their own needs (after WCED 1987) - yields many potential benefits, such as improving air and water quality, conserving natural resources, reducing operating costs, and increasing occupant productivity and satisfaction (Kibert 2008; Shah 2006; USGBC 2007, 2009). Accordingly, the construction industry has implemented many strategies and technologies for "green" buildings throughout the lifecycle.

\subsection{Modeling and Measuring Sustainability: The Challenges}

In its most literal sense, sustainability is a system state marked by stability, where changes to the system are constrained to ensure stability into the foreseeable future (Pearce 1999). This state depends not only on the system itself, but also on the context in which the system operates, and the evolving dependencies between them (DuBose 1994; Pearce 1999; Pearce and Vanegas 2002). Measuring sustainability poses a challenge to those who would use the concept as an objective for decision making, since measuring the sustainability of a given system requires knowledge not only of the behavior of the elements of the system itself, but also the ripple effects of the system due to its inputs from and outputs to the global Earth system. Conventional approaches rely upon indicators believed to reflect system sustainability. For example, the Leadership in Energy and Environmental Design (LEED) green building rating system is based on multiple categories of indicators that survived the rigor of a consensus process (USGBC 2007). While not comprehensive or collectively exhaustive, these indicators reflect critical system behaviors influencing sustainability, such as energy consumption, ecosystem disturbance, and waste generation.

Existing indicator-based approaches to sustainability evaluation have yet to be embedded effectively within decision making processes for built facilities. The LEED system, for example, is typically used as a means for establishing a rating for a given facility rather than as a tool for maximizing sustainability over the facility life cycle. It does not incorporate other typical constraints and considerations such as cost or availability of resources for a specific facility that are critical for meaningful decision making. A method of measuring sustainability for built facilities is needed that can be embedded within existing processes for capital facilities planning and resource allocation. Ideally, the approach should also address observed implementation barriers that are slowing adoption of sustainability in practice.

\section{COST-BASED SUSTAINABILITY MEASUREMENT}

An approach that can be embedded within conventional decision processes is to base sustainability evaluation on cost. To the extent that costs over the life cycle of a facility reflect demands for resources, life cycle costs are a proxy for external resource demand and thus correlate inversely with system sustainability. From a practical standpoint, facility costs also represent a feasibility criterion for a project in terms of an organization's ability to afford those costs over time as they occur. Other sustainability-related externalities such as damage to natural ecosystems can also be accounted for using a cost metric if desired (Bennett \& James 1998). Assuming that all direct and indirect costs and externalities are taken into account, the sustainability of a project should be inversely proportional to its total ownership costs over the 


\section{Pearce, Sanford-Bernhardt, and Garvin}

life cycle. To the extent that revenues are also taken into account, metrics such as net present value can then be used as a measure of the facility's impact on an organization's financial success.

\subsection{Total Cost of Ownership}

Total cost of ownership (TCO) is a metric of managerial and investment strategies, including sustainability initiatives, for capital projects in a portfolio context. Often considered to be equivalent to the lifecycle cost (LCC) of a facility, TCO considers both facility occupancy costs and hard capital costs. The International Facilities Management Association (IFMA) defines TCO as (IFMA 2008):

TCO...includes the representation of the sum total of the present value of all direct, indirect, recurring and non-recurring costs incurred or estimated to be incurred in the design, development, production, operation, maintenance of a facility/structure/asset over its anticipated lifespan. (Inclusive of site/utilities, new construction, deferred maintenance, preventive/routine maintenance, renovation, compliance, capital renewal, and occupancy costs.)

Current approaches to calculating TCO differ based on the type of decision making being supported by the calculation (Asiedu \& Gu 1998). At the project scale, TCO is often used as a metric for comparing project alternatives as part of planning or design, identifying cost drivers for design changes and optimization, or as a screening criterion for project funding (Arditi \& Messiha 1996; Asiedu \& Gu 1998; Keys 1990). A variety of "bottom up" models exist to estimate lifecycle costs at this scale, when projectspecific details are known to some degree (e.g., Asiedu \& Gu 1998, Zayed, Chang, and Fricker 2002).

At the portfolio scale, TCO is a useful metric for prioritizing facilities for repair or replacement in combination with other metrics such as safety, condition, utilization, or mission criticality - it helps to determine which facilities are costing the most to deliver the required function and what benchmark TCO is possible given other facilities in the portfolio (e.g., Liu \& Frangopol 2005). With an increase in portfoliobased management by public sector owners, decision makers would like to be able to accurately calculate what is the true TCO for each facility comprising a portfolio. Estimates of LCC or TCO may be required as part of funding requests for new facilities (e.g., State of Georgia 2007; NAVFAC 2007), but existing facilities often do not yield the necessary data to calculate TCO on an individual facilities scale.

\subsection{Cost Uncertainty over the Project Life Cycle}

When project details have not yet been developed, cost metrics are more difficult to develop with any certainty. Boehm's (1981) "cone of uncertainty" reflects the fact that as additional definition occurs for a project, uncertainty about its eventual cost decreases. The true cost of a project is only known when the project is complete. From a TCO standpoint, the cone also applies to future operational, maintenance, rehabilitation, retrofit, and eventual disposal costs of the facility. The immediate operational costs are known with greatest certainty at the beginning of the facility's service life, but are known with less certainty over time as components within the facility degrade at various rates and are maintained with varying degrees of rigor; utility costs change; and expectations for building services evolve.

Given that the decision to pursue a project or not may depend on a preliminary cost estimate, developing reliable cost estimates before investing in project design and development is essential. Conventionally, preliminary estimates for projects at the planning stage are based on historical data from similar projects. However, this approach is less applicable to innovative projects that are substantially different from past projects, and the historical data on green projects remains comparatively small. How, then, should decision-makers accurately develop early-stage estimates of innovative green projects?

\subsection{Status Quo Approaches to Cost Estimating for Green Capital Projects}

Green projects are characterized by several unique qualities: tightly coupled designs and multifunction materials and systems (Riley, Pexton, and Drilling 2003; Rohracher 2001), procurement of unusual products with limited sources (Klotz et al. 2007; Pulaski et al. 2003; Syphers et al. 2003), existence of incentives and resources not available to other projects (Grosskopf \& Kibert 2006; Pearce 2008; Rohracher 


\section{Pearce, Sanford-Bernhardt, and Garvin}

2001), requirements for additional information and documentation (Lapinski, Horman, and Riley 2005, 2006; Pulaski et al. 2003), and greater involvement and integration of input of later stakeholders in earlier project phases (Cole 2000; Gil et al. 2000; Pulaski \& Horman 2005; Pulaski, Horman, and Riley 2006; Reed \& Gordon 2000; Rohracher 2001). While some research exists to quantify the incremental costs for project design (Larsson \& Clark 2000; Enermodal Engineering 2006), incremental costs associated with changes to construction practice remain unexplored, and some authors assert that construction practice remains largely the same despite changes in project requirements (Dewick \& Miozzo 2004; Matar, Georgy, and Ibrahim 2008).

Tightly coupled integrated design of systems in green projects means that investment in better performing and more expensive systems of one type can result in savings in other systems, often substantially offsetting any additional cost associated with the more expensive systems as well as resulting in lifecycle savings (e.g., Kats 2004; Mogge 2004; Pearce 2008). The effects of integrated design are difficult to generalize from case to case and challenging to incorporate in preliminary or conceptual estimates for projects where design details are not developed to any degree, as is the case in public sector projects when initial funding requests are being made. Common practice for estimating sustainable project costs at the conceptual phase is to add a margin to the estimate for a traditional project to cover anticipated increases in design costs, material costs, and other project costs (Mogge 2004; NAVFAC 2008). This approach has the potential to inhibit the implementation of sustainability for several reasons (Pearce 2008). First, capital projects are typically funded based on efficiency of first cost, meaning that projects with a higher parametric cost estimate are less likely to get funded. Second, adding a premium to the project estimate means that even if the project is funded, the incentive to seek cost savings is reduced since the money will be lost if it is not spent, thereby creating a self-fulfilling prophecy of increased costs for sustainable projects.

Current approaches to estimating cost of green projects are thus lacking in several ways. First, current methods for estimating the first cost of green projects early in the project life cycle contain built-in assumptions that create an artificial cost margin for green projects, leading to a self-fulfilling prophecy that green projects necessarily cost more than conventional projects. Second, life cycle cost estimates are dependent upon building performance models that may poorly represent the actual operating costs of green projects (Hinge et al. 2006; Nelms, Russell, and Lence 2007; Newsham, Mancini, and Birt 2008; Turner 2006). Finally, the comparatively small pool of cost data on green projects provides a relatively weak basis for statistical or parametric approaches to costing green projects (Lapinski, Horman, and Riley 2006). A new approach is needed to account for actual differences between green and conventional projects rather than adding a margin to cost data for conventional projects. That approach should (1) be able to account for interactions among humans, context, and technology that comprise green buildings; (2) be usable at the very earliest stages of design before details about the project are well known; and (3) take into account the full set of costs associated with ownership of a facility to enable balanced allocation of resources across portfolios of facilities rather than sub-optimizing performance of a single project.

\section{MODELING TCO OF CAPITAL FACILITIES}

Total Cost of Ownership is an emergent property of systems at both the project and portfolio scales. At the scale of individual public sector projects, TCO is influenced by a number of factors throughout a constructed facility's lifecycle:

- Individual decisions made by a number of decision makers, including members of the design team, owner team, construction team, etc., based on a variety of technical and people-oriented factors.

- Selection of parties to participate in a capital project is stochastic and influenced by many factors (Keysar \& Pearce 2007; Pearce et al. 2005b).

- Initial program of requirements for the facility, which is necessarily different for each project and which is also influenced by contextual factors describing the environmental, sociopolitical, and 


\section{Pearce, Sanford-Bernhardt, and Garvin}

organizational context in which the facility will exist and operate (Pearce, DuBose, and Bosch 2007).

- Construction quality and congruence with original design intent (Newton \& Christian 2006).

- Availability of new technologies that can be applied to the facility over its lifecycle, resulting in new cost profiles that are different from those assumed during initial design and construction.

- Interactions between the facility and its occupants over the lifecycle, both in a formal sense of organizational mission requirements and in an informal sense, where users adapt, enhance, or disable technologies and systems within the facility to adjust it to their needs (e.g., Arpke \& Hutzler 2005).

\subsection{The Role of Stakeholders as Agents in TCO}

Figure 1 illustrates the complexity of relationships among stakeholders developing a facility up to the point of occupancy. In conventional project delivery, the Owner Team (OT) selects the Design Team (DT) and the Construct Team (CT) on the basis of firm capabilities, capacity to perform the work, history with the owner organization, and specific procurement restrictions such as minority business set-asides. Qualified teams may also be selected on the basis of criteria such as low bid or best value (Pearce 2008). Whether or not a given team is selected is also a function of market conditions and whether that team puts itself "on the market" for a given project given its capacity and load of other projects. Selection of the project team influences the first cost of a project, since the unique design of a specific project is influenced by the history and experience of each firm. For instance, design teams tend to favor proven technologies over unproven ones (Nam \& Tatum 1992). Owner and Construct organizations also favor technologies and practices successfully demonstrated on peer projects (Pearce et al. 2005a; Rogers 2003; Toole 1998; Koebel 1999; Koebel et al. 2003). The ultimate design (and subsequent performance) is determined by both system selection and specification by the Design Team, and methods selection and implementation by the Construct Team. These decisions are influenced as well by the history, knowledge, and social networks of the involved team members, the capabilities and capacity of team members' firms, and specific constraints/objectives imposed by the Owner Team. The result of these decisions is a facility with a Total Installed Cost (TIC) that then goes on to occupancy/beneficial use throughout the rest of its lifecycle with similar or even greater cost-determining complexity.

\subsection{Total Cost of Ownership at the Portfolio Scale}

At the portfolio scale, TCO represents an amalgamation of the TCO for each facility comprising the portfolio, but it is again an emergent property that is more complex than a simple sum of individual facility TCOs. Given that the portfolio as a whole is intended to meet the overall needs of the owner organization, entities within that organization and its sub-organizations can shift utilization of different facilities within the portfolio as appropriate to better meet the overall needs of the organization. In the context of a whole portfolio, less funding to each individual project means that more total projects can be funded, given a fixed capital budget. At the same time, there are minimum thresholds beneath which viable projects that meet owner requirements simply cannot be delivered. This research seeks to establish the relationships between initial investments in individual projects and the TCO of those projects as a basis for understanding how to most effectively allocate funding for capital projects, given the goals of minimizing TCO while meeting agency requirements.

\section{AN AGENT-BASED MODELING APPROACH TO TCO}

From a modeling standpoint, capturing the complexity of the socio-enviro-technical system that is a capital project presents a challenge. The objective of this research is to evaluate whether an agent-based modeling approach can be used to simulate the behavior of this complex system at key phases of the life cycle of a capital project so that total cost of ownership can be predicted more realistically than the simple cost margin approach used by institutional owners today. The approach taken in this project employs a broader 
perspective on project cost that recognizes the complex relationships between people, technology, and context that influence TCO over a facility's life cycle. Agent-based modeling (ABM) allows the simulation of this complex system and the emergent properties of the system, specifically TCO. An ABM approach is both modular (with model components able to be developed sequentially and replaced over time as new empirical data is obtained) and scalable (able to be combined into a larger ABM that represents portfolios of projects), thus providing the ability to evaluate scenarios at the facility and portfolio scales.

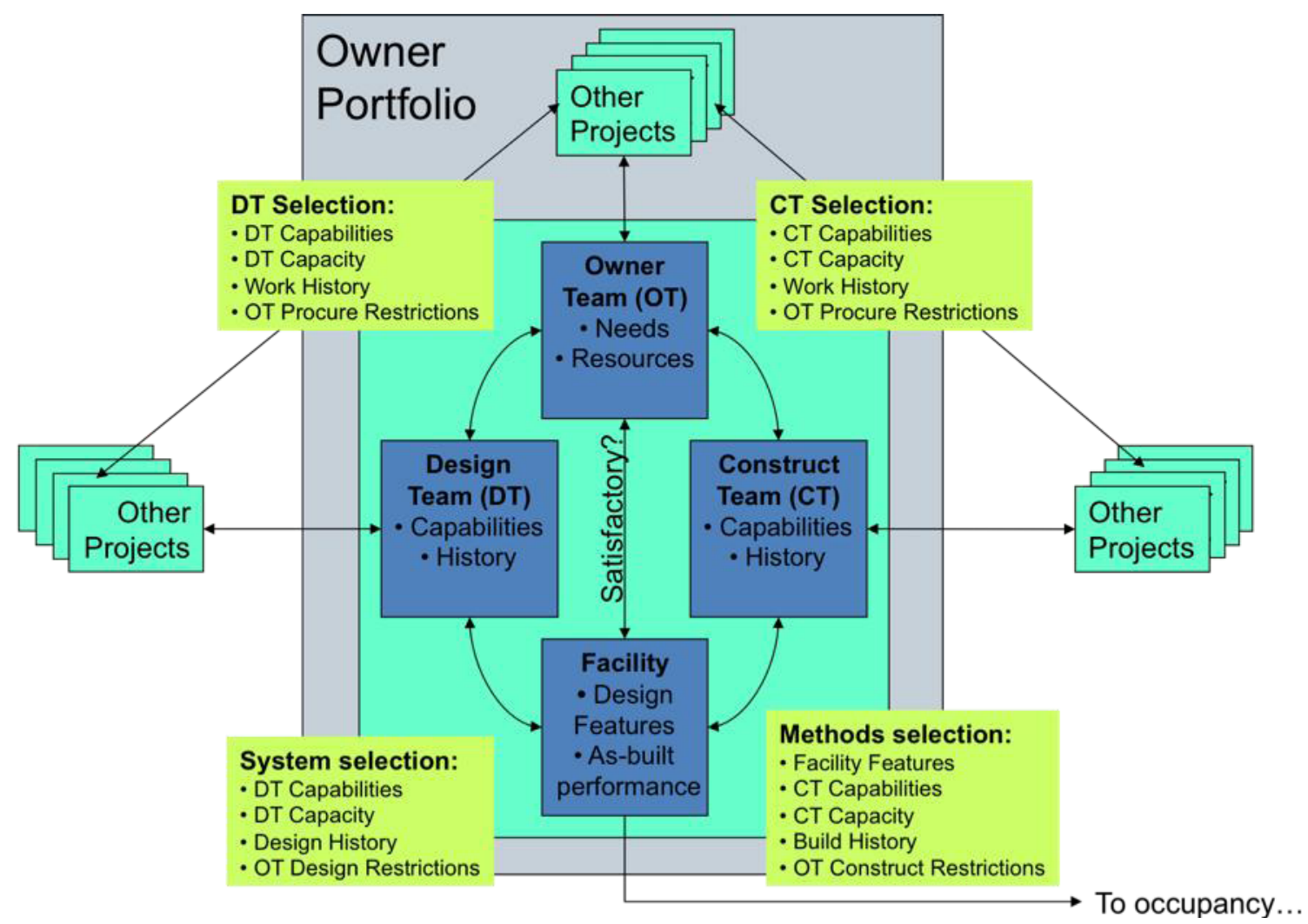

Figure 1: A project-scale model in the context of an owner portfolio involves multiple stakeholders who are also engaged in other projects at the same time

\subsection{Design Concepts for the Facility-Scale TCO Model}

One of the most significant aspects of the research to date has been determining how to conceptualize the project in a way that can be modeled effectively and tied to existing cost models. Existing approaches to life cycle costing can, with proper assumptions and sufficient information, reasonably predict TCO. The real challenge lies in making good assumptions at the conceptual stage of a project when relatively little is known about the project design, implementation, or use. Rather than reinventing existing approaches to costing, the focus of this research has been to use an ABM model to generate detailed inputs to existing cost models that can then be used to generate actual TCO estimates. To accomplish this aim, the overall project life cycle was divided into four major phases encapsulating critical decisions affecting TCO: project team formation, design, construction, and operations. Currently, the agents are defined as collections: owner, design and construction teams. Table 1 shows the typical interactions among agents within each phase. Each major stakeholder group (owner, designer, constructor) is likely to be involved in multiple projects at once and over time, and each group consists of a variety of individual agents acting purposively within the organization. Table 1 also reflects the decision made by the research team to model the facility's technological components or assemblies as agents themselves during the design phase to reflect the decisions made during system selection. 
Table 1: Various entities are involved in the planning, design, construction, and operations/maintenance (O\&M) of a capital facility during its life cycle.

\begin{tabular}{|c|c|c|c|c|}
\hline & Team Formation & Design & Construction & O\&M \\
\hline 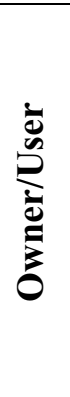 & $\begin{array}{l}\text { Specifies project } \\
\text { need and feasibility } \\
\text { constraints; chooses } \\
\text { design/construct ent- } \\
\text { ities for the project } \\
\text { from those circulat- } \\
\text { ing in the market at } \\
\text { the time of selection }\end{array}$ & $\begin{array}{l}\text { Reviews and approves } \\
\text { or rejects system selec- } \\
\text { tion decisions based on } \\
\text { past experience (if } \\
\text { any) with each system }\end{array}$ & $\begin{array}{l}\text { Observes installation of } \\
\text { systems, which influ- } \\
\text { ences experience with } \\
\text { component technolo- } \\
\text { gies for future projects; } \\
\text { approves substitutions } \\
\text { if required during con- } \\
\text { struction }\end{array}$ & $\begin{array}{l}\text { Interacts with facility } \\
\text { technologies in ways } \\
\text { that result in opera- } \\
\text { tions or maintenance } \\
\text { costs; adjusts opi- } \\
\text { nions of components } \\
\text { that will influence se- } \\
\text { lection on future } \\
\text { projects }\end{array}$ \\
\hline 离 & $\begin{array}{l}\text { Responds to relevant } \\
\text { project opportunities } \\
\text { as long as capacity } \\
\text { exists; selection } \\
\text { attributes include } \\
\text { design philosophy } \\
\text { and past experience } \\
\text { with similar projects }\end{array}$ & $\begin{array}{l}\text { Develops configura- } \\
\text { tions of building sys- } \\
\text { tems to improve upon } \\
\text { prototype design sup- } \\
\text { plied by owner; influ- } \\
\text { ences these configura- } \\
\text { tions based on past } \\
\text { experiences with com- } \\
\text { ponent systems }\end{array}$ & $\begin{array}{l}\text { Observes installation of } \\
\text { systems, which influ- } \\
\text { ences experience with } \\
\text { component technolo- } \\
\text { gies for future projects; } \\
\text { supplies substitutions if } \\
\text { required during con- } \\
\text { struction }\end{array}$ & $\begin{array}{l}\text { Not involved except } \\
\text { for possible feedback } \\
\text { on systems perfor- } \\
\text { mance and client sa- } \\
\text { tisfaction with design } \\
\text { decisions }\end{array}$ \\
\hline ن & $\begin{array}{l}\text { Responds to relevant } \\
\text { project opportunities } \\
\text { as long as capacity } \\
\text { exists; selection } \\
\text { attributes includes } \\
\text { past experience with } \\
\text { similar projects }\end{array}$ & $\begin{array}{l}\text { Supplies price infor- } \\
\text { mation for design sce- } \\
\text { narios based on prior } \\
\text { experience and market } \\
\text { conditions }\end{array}$ & $\begin{array}{l}\text { Coordinates installation } \\
\text { of systems using sub- } \\
\text { contractor and supplier } \\
\text { agents; costs based on } \\
\text { market condition and } \\
\text { prior experience with } \\
\text { each component type }\end{array}$ & $\begin{array}{l}\text { Limited involvement } \\
\text { for callbacks to han- } \\
\text { dle warranty issues; } \\
\text { no influence on cost }\end{array}$ \\
\hline 产 & $\begin{array}{l}\text { Not involved unless } \\
\text { modeling resource } \\
\text { scarcity issues in the } \\
\text { market }\end{array}$ & $\begin{array}{l}\text { Gravitate toward or } \\
\text { away from prototype } \\
\text { design within decision } \\
\text { space; are either re- } \\
\text { jected or incorporated } \\
\text { based on whether they } \\
\text { can improve perfor- } \\
\text { mance and "greenness" } \\
\text { without violating con- } \\
\text { straints }\end{array}$ & $\begin{array}{l}\text { Pair with subcontractor } \\
\text { and supplier agents to } \\
\text { be procured and in- } \\
\text { stalled on project, sub- } \\
\text { ject to market con- } \\
\text { straints; may provide a } \\
\text { positive or negative ex- } \\
\text { perience for associated } \\
\text { agents }\end{array}$ & $\begin{array}{l}\text { Interact with own- } \\
\text { er/user agents to re- } \\
\text { sult in operations and } \\
\text { maintenance costs } \\
\text { such as energy use, } \\
\text { water use, componen } \\
\text { repair and replace- } \\
\text { ment, etc. }\end{array}$ \\
\hline
\end{tabular}

\subsection{Example: Developing a Specification for the Facility Design Module}

One example of the approach taken in this research to defining the functionality of the ABM is the development of the design module. Suppose that the primary agents in the design-phase model are assemblies representing individual building systems such as foundations or flooring, or sustainability-related technologies or practices such as rainwater harvesting systems or on-site recycling. These agents are observed by (and exchange information with, in various ways,) the three primary human agent collections for a specific project: the designer, the constructor, and the owner. An assembly in this case was defined as any set of building practices or components with an identifiable function that might be implemented by a subcontractor as part of a project. The UNIFORMAT II classification of building elements and related sitework (see Robert P. Charette Consultants Inc. 2010) was used to determine which assemblies to include. 


\section{Pearce, Sanford-Bernhardt, and Garvin}

To bound the design process for initial model development, prototype design was used. Prototype design is an approach used by institutional owners in both the public and private sectors with many similar facilities to obtain consistent buildings across multiple projects. Examples include the U.S. Postal Service, the State of Georgia school system, banks with multiple branches, hotels, and big box stores. In this approach, design prototypes are created that specify the basic systems for a particular building type. The prototype then serves as a starting point that is customized to meet specific site conditions. For the ABM, a prototype building is established that consists of a predetermined set of compatible assemblies of different types that can be supplemented or replaced by other assemblies "available" in the decision space. Each of the assemblies has, at a minimum, a total installed cost, an affinity with respect to the project at hand, a life cycle cost impact function, and a separate sustainability function to capture externalities or non-quantified costs and/or benefits associated with it. The model begins with the prototype set of assemblies in the center of the decision space, affiliated with each other to form a complete building. Additional candidate assemblies are arbitrarily distributed throughout the space.

With each iteration of the model, assemblies not included in the building design change based on their affinity with respect to the project. In the design phase TCO model, affinity is a function of prior experience on the part of any stakeholder (designer, constructor, owner) with that assembly (either positive or negative), and a contextual appropriateness function based on attributes of the project context, which must be seeded with basic project parameters provided by the user such as climate, development density, etc. Assemblies with higher affinity for the project move more quickly toward the prototype building, while those with lesser affinity move more slowly toward the building, and those with negative affinity move away from the building. When an assembly reaches the building, it is compared with the corresponding assembly in the prototype. If the new assembly is better than the existing assembly according to the life cycle cost impact function and/or sustainability impact function, it displaces that assembly, which is either discarded or sent back to the decision space. If it is worse than the existing assembly, it is returned to the decision space. If there is no corresponding assembly in the building (i.e., if the new assembly would be an add-on rather than a substitution), it could be added to the building scope if it improves any of the objective functions while remaining within the constraints.

Total installed cost of the prototype as a whole (i.e., all the assemblies included as part of the building at any point in time) could be either a constraint or an objective function when determining whether to substitute or add a new assembly. Within the decision space, multiple assemblies can also reach the project at the same time and be accepted based on their joint effects on the prototype building, whereas they might be rejected if they were considered individually. Incoming assemblies should also be able to displace multiple existing assemblies, e.g., a new reflective roof replacing not only the roof but also allowing for downsizing the building cooling system as well. Life cycle cost impact is determined by querying the owner agent whenever an assembly reaches the location of the building. The life cycle cost of that assembly could be approximated stochastically each time the query is made. Owner response to a cost query is a module to be developed in future research in more detail, and may be a function of expected use of the facility, availability of maintenance resources, and other factors to reflect uncertainties associated with future building use or changes in resource prices. Other sustainability impact is determined by querying the designer agent whenever an assembly reaches the location of the building. This objective function is necessary to capture some of the externalities that drive system selection decisions, such as visibility/prestige of "greener" finishes, overall societal benefits, and others. The LEED rating system encourages behaviors that have better performance with respect to economic externalities, so it may be a reasonable approximation of these externalities as well as a widely recognizable metric used by industry stakeholders.

When the model reaches a steady state, the sum of the total installed costs of all assemblies is the first cost of the project, and the sum of the operating/use period costs of all assemblies is the life cycle cost of the project. The sum of these two represents the total cost of ownership of the facility as estimated at the end of the design phase. The configuration of assemblies comprising the design then feeds into subsequent modules for construction and O\&M to further refine the cost estimate. This representation approx- 


\section{Pearce, Sanford-Bernhardt, and Garvin}

imates a design-build approach to a project. For a design-bid-build approach, constructor bids could be determined using the total installed cost query function for all assemblies together for a complete building scope. That scope could be specified in advance by the user, or could be determined in other ways as well such as using the prototype design without modification.

\subsection{Results to Date}

To date, conceptual models have been developed for project team formation and design. Detailed models for construction and operations are under development. The process for determining model functionalities and structure has involved developing a basic strawman of system performance based on literature review for the behaviors and functional relationships among key agents, followed by adjustment and validation using stakeholder interviews and field observations. Partner organizations for the project include the U.S. Postal Service (Ahn 2010) and the U.S. Naval Facilities Command. The approach to model development was based on a hierarchy of cascading complexity. Starting at the individual project scale, the fundamental agents were defined at a low resolution and a working model was developed at this resolution before more detail was introduced. As the composite model is developed, it is verified against cost data for prototype projects using various green technologies and practices developed through simulation and validated against project data from partner organizations (ibid.). Development of modules to represent increasing levels of detail is part of further research to be conducted in subsequent years of the project.

\section{THE FUTURE: MODELING TO OPTIMIZE POLICIES AND DECISION MAKING}

The initial results of using agent-based modeling to predict TCO are promising. An ABM approach offers the ability not only to nest models to capture the behavior of individuals within organizations, but also to scale up the model as a more complex representation of the marketplace. Ultimately, the aim is to develop a larger scale model that can simulate the effects of public policy on diffusion and adoption of green technologies and practices. For instance, the relationship between initial investments in high performance facilities and their overall lifecycle performance is a challenge on the scale of both individual facilities and the portfolios of which they are a part, since resources available to those portfolios are ultimately finite and must be allocated fairly among projects to optimize agency outcomes. A portfolio-scale model of TCO based on individual facility models could help to understand the impacts of uniform vs. differential investments in green building. For example, are the best results achieved by allocating X\% more funds to improve the energy performance of all projects, or should the total amount be focused on a Pareto subset of projects that are likely to have the greatest impacts? While intuition may tell us that the latter strategy will be more effective, what impact does it have on human behavior associated with facilities that are not exceptional? Is less attention then paid on those projects to meeting energy efficiency goals?

Such a model could also provide a perspective on the most effective way to mandate action to improve overall portfolio performance. For instance, are prescriptive requirements for building improvement most effective (e.g., "all facilities must use technology X")? Or are performance-based requirements (e.g., "all facilities must use whatever technologies are appropriate to achieve energy reduction Y") likely to be more effective in influencing overall performance across a portfolio? Being able to accurately model the response of coupled technological and human systems to policy intervention through simulation will provide a better approach to policy design that permits experimentation without the risks inherent in policy trial and error on a full scale. Ultimately, the outcomes of this research will further the goals of sustainability in public sector capital projects by providing a more realistic and accurate picture of the relationships between investment and outcomes, and generating the knowledge that is needed to direct limited resources where they can do the most good. 


\section{ACKNOWLEDGMENTS}

This work was funded by grant 0828779 from the National Science Foundation, whose support is gratefully acknowledged. Any opinions, findings, conclusions, or recommendations expressed in this paper are those of the writer and do not necessarily reflect the views of the National Science Foundation.. The authors would like to thank the students who have supported the project at both universities, including Sushil Shenoy, Adam Hise, Yong Han Ahn, Sandeep Langar, and Chayanika Mitra (Virginia Tech), and Mosi London, Cara Lyons, Peter Mara, and Stephanie Mason (Lafayette).

\section{REFERENCES}

Ahn, Y.H. 2010. Sustainability investments for capital project portfolios. Ph.D. Dissertation, Environmental Design and Planning, Virginia Polytechnic Institute and State University, Blacksburg, VA.

Arditi, D.A. and H.M. Messiha. 1996. Life-cycle costing in municipal construction projects. Journal of Infrastructure Systems 2(1):5-14.

Arpke, A., and N. Hutzler. 2005. Operational life-cycle assessment and life-cycle cost analysis for water use in multioccupant buildings. Journal of Architectural Engineering 11(3): 99-109.

Asiedu, Y., and P. Gu. 1998. Product life cycle cost analysis: state of the art review. International Journal of Production Research 36(4):883-908.

Boehm, B.W. 1981. Software engineering economics. Upper Saddle River, NJ: Prentice Hall.

Bennett, M. and P. James. 1998. The green bottom line: environmental accounting for management. Sheffield, UK: Greenleaf Press.

Cole, R.J. 2000. Cost and value in building green. Building Research \& Inf. 28(5/6):304-309.

Dewick, P., and M. Miozzo. 2004. Networks and innovation: sustainable technologies in Scottish social housing. $R \& D$ Management 34(3):323-333.

DuBose, J.R. 1994. Sustainability as an inherently contextual concept: some lessons from agricultural development. School of Public Policy, Georgia Institute of Technology, Atlanta, GA.

Enermodal Engineering. 2006. The cost and benefits of LEED-NC in Colorado. Governor's Office of Energy Management and Conservation, State of Colorado, Denver, CO.

Fisk, W.J. 2000. Health and productivity gains from better indoor environments and their relationship with building energy efficiency. Annual Review of Energy and Envt. and Resources, 25:537-566.

Fisk, W.J., and A.H. Rosenfeld. 1997. Estimates of Improved Productivity and Health from Better Indoor Environments. Indoor Air 7(3):158-172.

Gil, N., I.D. Tommelein, R.L. Kirkendall, and G. Ballard. 2000. Contribution of specialty contractor knowledge to early design. Proc. Eighth Annual Conference of the International Group for Lean Construction (IGLC-8), 17-19 July, held in Brighton, UK.

Grosskopf, K.R., and C.J. Kibert. 2006. Developing market-based incentives for green building alternatives. Journal of Green Building 1(1):141-147.

Hill, R.C., and P.A. Bowen. 1997. Sustainable construction principles and a framework for attainment. Construction Management and Economics 15(3):223-239.

Hinge, A., D. Winston, B. Stigge, and B. Happold. 2006. Moving toward transparency and disclosure in the energy performance of green buildings. American Council for an Energy Efficient Economy. Washington, DC.

IFMA. 2008. Asset lifecycle model for total cost of ownership management: framework, glossary, and definitions. International Facilities Management Association. Available via <http://www.ifma.org/tools/research/Asset_Lifecyle_Model.pdf> [accessed April 14, 2010].

Kats, G. 2003. The costs and financial benefits of green buildings. A Report to California's Sustainable Building Task Force, Sacramento, CA. 
Kats, G.H. 2004. Green building costs and financial benefits. A Report to California's Sustainable Building Task Force, Capital E. Available via <http: / / www . cap-e.com> [accessed April 14, 2010].

Keys, L.K. 1990. System life cycle engineering and DF 'X'. IEEE Transactions on Components, Hybrids, and Manufacturing Technology 13(1):83-93.

Keysar, E., and A.R. Pearce. 2007. Decision support tools for green building: facilitating selection among new adopters on public sector projects. Journal of Green Building 2(3):153-171.

Kibert, C.J. 2008. Sustainable construction: green building design and delivery. 2 Ed., Hoboken, NJ: John Wiley \& Sons,.

Klotz, L., M. Horman, and M. Bodenschatz. 2007. A lean modeling protocol for evaluating green project delivery. Lean Construction Journal 3(1):1-18.

Koebel, C.T. 1999. Sustaining sustainability: innovation in housing and the built environment. Journal of Urban Technology 6(3):75-94.

Koebel, C.T., M. Papadakis, E. Hudson, and M. Cavell. 2003. The diffusion of innovation in the residential building industry. U.S. Department of Housing and Urban Development, Office of Policy Development and Research, Washington, DC.

Lapinski, A.R., M.J. Horman, and D.R. Riley. 2005. Delivering sustainability: lean principles for green projects. Proceedings, 2005 ASCE Construction Research Congress.

Lapinski, A.R., M.J. Horman, and D.R. Riley. 2006. Lean processes for sustainable project delivery. Journal of Construction Engineering and Management 132(10):1083-1091.

Larsson, N., and J. Clark. 2000. Incremental costs within the design process for energy efficient buildings. Building Research \& Information 28(5/6):413-418.

Liu, M., and D.M. Frangopol. 2006. Optimizing bridge network maintenance management under uncertainty with conflicting criteria: life-cycle maintenance, failure, and user costs. Journal of Structural Engineering 132(11):1835-1845.

Matar, M.M., M.E. Georgy, and M.E. Ibrahim. 2008. Sustainable construction management: introduction of the operational context space (OCS). Construction Mgt. and Economics 26(3):261-275.

MGD 2000. United nations millennium development goals. United Nations. Available via <http://www.un.org/millennium/declaration/ares552e.pdf> [accessed April 14, 2010].

Mogge, J.W. 2004. Breaking through the first cost barriers of sustainable planning, design, and construction. School of Civil \& Environmental Eng., Georgia Institute of Technology, Atlanta, GA.

NAVFAC. 2007. Cost engineering: policies and procedures. Naval Facilities Engineering Command. Available via <http://www.uscost.net/costengineering/Documents/policyprocedures.pdf $>$ [accessed April 15, 2010].

NAVFAC. 2008. Navy DD 1391 sustainable design cost tool. Naval Facilities Engineering Command. Available via $<$ http://www.wbdg.org/docs/navy_1391_leed.xls $>$ [accessed April 15, 2010].

Nam, C.H., and C.B. Tatum. 1992. Noncontractual methods of integration on construction projects. $J$. Constr. Engrg. and Mgmt. 118(2):385-398.

Nelms, C.E, A.D. Russell, and B.J. Lence. 2007. Assessing the performance of sustainable technologies: a framework and its application. Building Research and Information 35(3):237-251.

Newsham, G., S. Mancini, and B. Birt. 2008. Do LEED-certified buildings save energy? yes, but...” Energy and Buildings 41(8):897-905.

Newton, L.A., and J. Christian. 2006. Impact of quality on building costs. Journal of Infrastructure Systems 12(4):199-206.

Pearce, A.R. 1999. Sustainability and the built environment: a metric and process for prioritizing improvement opportunities. Civil \& Environmental Eng., Georgia Inst. of Technology, Atlanta, GA.

Pearce, A.R. 2008. Sustainable capital projects: leapfrogging the first cost barrier. Civil Engineering and Environmental Systems 25(4):291-300. 
Pearce, A.R., J.R. DuBose, and S.J. Bosch. 2007. Green building policy options in the public sector. Journal of Green Building 2(1):156-174.

Pearce, A.R., J.R. DuBose, S.J. Bosch, and A.M. Carpenter. 2005a. Sustainability and the state construction manual: Georgia-specific voluntary guidelines. Final Project Report to the Georgia State Finance and Investment Commission, Atlanta, GA, December.

Pearce, A.R., S.J. Bosch, J.R. DuBose, A.M. Carpenter, G.L. Black, G.L., and J.A. Harbert. 2005b. The Kresge Foundation and GTRI: The far-reaching impacts of green facility planning. Final Project Report to the Kresge Foundation, Troy, MI, June 30.

Pearce, A.R. and J.A. Vanegas. 2002. Defining sustainability for built environment systems. International Journal of Environmental Technology and Management 2(1):94-113.

Pulaski, M.H., and M.J. Horman. 2005. Organizing constructability knowledge for design. Journal of Construction Engineering and Management 131(8):911-919.

Pulaski, M.H., M.J. Horman, and D.R. Riley. 2006. Constructability practices to manage sustainable building knowledge. Journal of Architectural Engineering 12(2):83-92.

Pulaski, M., T. Pohlman, M. Horman, and D. Riley. 2003. Synergies between sustainable design and construction at the Pentagon. Proceedings, 2003 ASCE Construction Research Congress.

Reed, W.G., and E.B. Gordon. 2000. Integrated design and building process: what research and methodologies are needed? Building Research \& Information 28(5/6):325-337.

Riley, D., K. Pexton, and J. Drilling. 2003. Procurement of sustainable construction services in the United States. UNEP Industry and Environment 26(2/3):66-69.

Robert P. Charette Consultants Inc. 2010. UNIFORMAT II... improving building investment performance. Available via <http: / / www . uniformat. com > [accessed April 15, 2010].

Rogers, E.M. 2003. Diffusion of innovations. $5^{\text {th }}$ ed. New York, NY: Free Press.

Rohracher, H. 2001. Managing the technical transition to sustainable construction of buildings: a sociotechnical perspective. Technology Analysis \& Strategic Management 13(1):137-150.

Roodman, D.M., and N. Lenssen. 1995. A building revolution: how ecology and health concerns are transforming construction. Worldwatch Institute, Washington, DC.

Shah, S. 2006. Sustainable practice for the facility manager. Oxford, UK: Blackwell Publishing.

State of Georgia. 2007. State of Georgia construction manual. Georgia State Finance and Investment Commission, Construction Division, Atlanta, GA. Available via $\langle\mathrm{http}: / / \mathrm{ww} \cdot \mathrm{scm} \cdot \mathrm{ga} \cdot \mathrm{g} \circ \mathrm{v}\rangle$ [accessed April 15, 2010].

Syphers, G., M. Baum, D. Bouton, and W. Sullens. 2003. Managing the cost of green buildings. State of California's Sustainable Building Task Force, Sacramento, CA.

Toole, T.M. 1998. Uncertainty and homebuilders' adoption of technological innovations. Journal of Construction Engineering \& Management 124(4):323-332.

Turner, C. 2006. LEED building performance in the Cascadia region. Proc., Cascadia Region Green Building Council. Portland, OR.

USGBC. 2007. New construction \& major renovation: reference guide. U.S. Green Building Council, Washington, DC.

USGBC. 2009. About USGBC. U.S. Green Building Council, Washington, DC. Available via <http://www.usgbc.org/DisplayPage.aspx?CMSPageID=124> [accessed April 15, 2009].

WCED. 1987. Our common future. World Commission on Environment and Development, Oxford, UK.

Zayed, T.M., L.M. Chang, and J.D. Fricker. 2002. Life-cycle Cost Analysis using Deterministic and Stochastic Methods: Conflicting Results. J. Performance of Constructed Facilities 16(2):63-74.

\section{AUTHOR BIOGRAPHIES}

ANNIE R. PEARCE is an Assistant Professor in the Department of Building Construction, MyersLawson School of Construction at Virginia Tech specializing in sustainable facilities and infrastructure 
systems. Her specific areas of interest include metrics of sustainability for built facilities, green building materials and systems, cost modeling to support sustainability implementation, and in situ performance of sustainable facility technologies. She has a B.S. Civil Engineering from Carnegie Mellon, and M.S. and Ph.D. Civil Engineering from Georgia Tech. Her email address is <apearce@vt. edu>.

KRISTEN L. SANFORD BERNHARDT is an Associate Professor in the Department of Civil \& Environmental Engineering and Chair of the Engineering Studies Program at Lafayette College. Her research interests are in the general areas of sustainable civil infrastructure management and transportation systems, with particular emphasis on data requirements, decision support, and applications of new technology. She received her Ph.D. and M.S. from Carnegie Mellon University, and her B.S.E. from Duke University, all in Civil and Environmental Engineering. Her email address is <sanfordkelafayette.edu>.

MICHAEL J. GARVIN is an associate professor in the Myers-Lawson School of Construction at Virginia Tech. His research and teaching focuses on the programming, financing, and delivery of large-scale infrastructure projects. He has a particular interest in the structure and effectiveness of infrastructure public-private partnerships. He received a B.S. Civil Engineering from the United States Military Academy and MS and $\mathrm{PhD}$ degrees from the Massachusetts Institute of Technology. His email address is <garvin@vt.edu>. 